\title{
The Study of Welfare Level of Migrants in Malaysia
}

\author{
Yon Virgo ${ }^{1}$ and Ainin Safarah Binti Musa ${ }^{2}$ \\ ${ }^{1)}$ Graduate Student of Geography Education, Universitas Negeri Padang, Indonesia \\ e-mail: yonvirgojvct@gmail.com \\ 2) Student of Geography, Malaya University, Malaysia \\ e-mail: aininsafarah@gmail.com
}

*Corresponding Author, Received: September 14, 2018, Revised: October 21, 2018, Accepted: December 05, 2018

This is an open acces article distributed under the Creative Commons 4.0 Attribution License, wich permits unrestricted use, Distribution, and reproduction in any medium provided the original work is properly cited @2017 by author and Universitas Negeri Padang

\begin{abstract}
The purpose of this study was to determine the level of understanding of migrant communities in Malaysia. This research used the descriptive qualitative technique by using interviews and documentation of the data. The type of data is primary data and secondary data. Primary data is collected by interviewed of resources and observation or open observations related to the welfare of migrants while Secondary data is obtained by searching through the internet in relation to information about the welfare situation of newcomers and documents that have been published by the relevant agencies. The results are obtained as follows: 1. For the income of migrants, they felt that their income is sufficient to fulfil their needs, some migrants could send money to their home countries 2. The Malaysian government paid attention to the education of immigrant children by allowing them to attend public schools except for foreigners without a permit. Malaysia also gave permission to foreign countries to establish expatriate schools for residents who live in Malaysia so that they can obtain an education in accordance with the curriculum and language of the country of origin. 3. In general, the place of residence of migrants is in a place far from the centre of the crowd, because they want a cheaper rental price. In term fulfilling food or consumption needs, the migrants claimed to have no problems, because the consumption costs were quite cheap 5 . Health services for migrants were relatively cheap at around RM15 for those who became Unlicensed Foreigners.
\end{abstract}

Keywords: Welfare, Community, Migrants

\section{Introduction}

Welfare means being born physically and mentally (Hermon, 2001; Hermon, 2010). Nuzuliani Adetya (2013) said that social welfare is a condition that can be met by the material, spiritual and social needs of an individual in order to live properly and be able to develop themselves and carry out social functions. Efforts to realize a social welfare include social rehabilitation, social protection and social security (Hermon et al., 2018). Social welfare is a system of social and material life both materially and spiritually that is overwhelmed by a sense of safety, inner and inner peace that allows for every citizen to carry out physical, spiritual and social needs for himself and his family by upholding human rights and obligations. Increased welfare needs to be realized (Hermon, 2012; Hermon, 2015). One of the factors to realize this is when the availability of employment with adequate income, adequate in meeting basic needs such as adequate and nutritious food, the existence of housing that is sufficient, clean and healthy, the fulfilment of children's educational needs and the health of an individual or group. All of the above will be realized if there is sufficient income from the income of a household head. People who work on something or a job are called labor Almost all of the countries have problems with employment that always grow and develop, both in developed and developing countries, both those who apply the ideology of capitalism and socialism 
(Yuningrum, 2010; Hermon, 2016a; Hermon, 2017). It can be seen from the existence of a department that manages labor in every cabinet that is formed. It's just that the reality of each country provides a variety of real problems so that sometimes raises various alternative solutions. Generally, developed countries are engaged in labor problems related to the "expensive" salary of workers, increasing unemployment due to mechanization (robotization), illegal labor, and demands for improvement of economic and social status. Meanwhile, in developing countries have employment problems which are related to the lack of employment opportunities, high unemployment rates, low human resource capacity, low salary levels, and almost no social security. Moreover, the treatment of employers who harm workers, such as mistreatment, immorality, humiliation, sexual harassment, prohibition of veiling, worship, and others. There are several problems related to employment: (1) salary / UMR problems. One of the problems that directly touch the workers is the low or inappropriate income (salary) obtained by the demand to fulfil their living needs and their dependents. This problem arises because life needs are increasing, while salaries received are relatively fixed. (2) Life Welfare Problems. When workers only have a source of income in the form of salaries (wages), then achieving welfare depends on the ability of the salary to meet various needs of life (Hermon, 2016b)

In line with population growth, there was an increase in the necessities of life, well both quantity and quality. While the availability of land resources, where humans get satisfaction the necessities of life are fixed and very limited. this will encourage people to find work up to other countries (Hermon, 2010). Rowley Chrish (2007) stated that labor is needed by the Malaysian state because it is able to make a very important contribution to the success of a country. Malaysia's Immigrant Position Statistics, 2017 stated there are at least 12 countries originating from contributing legal labor in Malaysia. The following table is the migrants' table number who work in Malaysia.

Table 1. Number of Legal Foreign Workers in Malaysia June, 30 2017

\begin{tabular}{|l|l|l|}
\hline No. & \multicolumn{1}{|c|}{ Country } & \multicolumn{1}{|c|}{ Number of foreign workers } \\
\hline 1 & Indonesia & 728.870 \\
\hline 2 & Nepal & 405.898 \\
\hline 3 & Bangladesh & 221.089 \\
\hline 4 & Myanmar & 127.705 \\
\hline 5 & India & 114.455 \\
\hline 6 & Pakistan & 59.281 \\
\hline 7 & Vietnam & 29.039 \\
\hline 8 & Tiongkok & 15.399 \\
\hline 9 & Thailand & 12.603 \\
\hline 10 & Srilanka & 5.964 \\
\hline 11 & Cambodia & 5.103 \\
\hline 12 & Laos & 3.900 \\
\hline Total & & 1.781 .598 \\
\hline
\end{tabular}

From the table above we can see that Indonesia is the largest country in contributing workers in Malaysia, amounting to 728.9, then Nepal 405.889, Bangladesh 221,089, Myanmar 127,705, India 114,455, Pakistan 59,281, Vietnam 29,039, China 15,399, Thailand 12,603, Sri Lanka 5,964, Cambodia 5,103. and Laos 3,900. On the other hand, the total growth of labor force in Malaysia from 2014 to 2018 was 14.3 in 2014, 14.5 million in 2015, 14.7 million in 2016, 15.1 million in 2017, 15, 36 million people in May 2018 (KPPDNKK Main Statistics January 2018). The increasing number of workers who come to Malaysia will have their own problems for the Malaysian government and themselves. Therefore, researchers are interested in conducting an analysis related to the welfare of migrants in Malaysia.

\section{Method}

This research is qualitative descriptive research (Hermon et al., 2008). Maleong (2005) stated that the main source of qualitative research is words, additional data such as journals, documents and others. This research used observation, interview, and documentation study to collect the data. The type of data were primary data and secondary data which obtained from the interview process with the community. Primary 
data was collected by interviewing resource persons and conducting observations or open observations related to the level of welfare of migrants, internet searches relating to information on the welfare of migrant communities in Malaysia, as well as documents published by relevant agencies.

\section{Results and Discussion}

\section{Income}

Getting a large salary is the desire of every worker. They are willing to leave their homeland and choose to move to another country. One of the destination countries for workers is in Malaysia. Norlati \& Usman (2014) stated that Malaysia's population has increased dramatically since more than 6 decades ago, which increased to 6.1 million in 1950 to 27.5 million people in 2010 . While in 2018 the population of Malaysia is estimated to reach 32, 4 million people, which increased by $1.1 \%$ from 2017 yesterday (Malaysian Fighter Position, 2018). Newcomers in Malaysia come from various countries, including Indonesia, China, Nepal, Vietnam, India, Pakistan and Bangladesh. The newcomers work as domestic servants, figure guards, garden guards, cleaning services, and hotel employees. This is caused by various skills and education ranging from only elementary school to undergraduate graduates. Besides that, the Malaysian native choose terms of work, if the work is classified as 3D dirty, Danger, they will not take it

According to the Malaysian statistics department, almost every year citizens get a raise, this is evidenced by the data in 2015 the average monthly wage in Malaysia was RM2,312 and in 2016 the average monthly wage was RM2,463 which increased in 2016 as much 6.3\% (Malaysian 2017 Position). Whereas in 2017 the average monthly wage in Malaysia was RM2,657 and in 2018 the average monthly wage was RM2,880 which experienced an increase of 8.1\% (Malaysia 2017 Position). While the average salary of employees based on their education is as follows: no education of RM1,410, Low Education RM1,649, Intermediate RM2,055, and for Undergraduate RM4,320.

The newcomers get paid according to work. The minimum wage for workers on the Malay Peninsula is RM1,000. Overtime hours are also paid outside the basic salary with the rule of $1.5 \mathrm{x}$ hourly wages on weekdays, $2 \mathrm{x}$ hourly wages on rest days and $3 \mathrm{x}$ regular wages on public holidays. (Migrant Workers Resources, 2017). They get Salaries depending on the type of work ranging from RM800 to RM3,000 per month depending on the agreement between the worker and his employer. for example, the shopkeeper is RM200.00.00 per month, for a rough worker RM1 .500. while woodworking workers in the forest reach RM2,000 per month. Whereas a teacher has an income of between RM2500 and RM3,000. They still are able to save money with their income. Furthermore, most of them can still send money to their families in hometowns. Their reason is to help families and save money for the business.

Some newcomers already have their own businesses. Especially those who have moved citizenship to become Malaysians. Initially, their arrival was as workers but when they had enough money they stopped and bought land legally according to the applicable procedures and set up their own buildings. Most of them work as a trader and some have their own shops, construction workers etc.

\section{Education}

The Malaysian government allows official or legal immigrant's children to get an education in public schools. The Malaysian government also provides 2 types of schools whose management is handed over to foreigners, namely international schools and Expatriate School. One example is the Sekolah Indonesia Luar Negri as SILN. SILN belongs to the type of expatriate school. International schools are educational institutions that provide PAUD to secondary school education using foreign country curricula with English as the medium of instruction. While the expatriate school is an educational institution that provides PAUD to high school level using the curriculum of the country of origin and using the official language of each country. As quoted in the SILN Bulletin, the school initiated by SIKL by the Indonesian Embassy in Kuala Lumpur was later inaugurated on 10 July 1969 by Minister of Education Malaysia, Dato 'Haji Abdul Rachman Yakob. This school is located in Lorong Tun Ismail No. 1. It can be accessed by using public transportation such as taking a bus or train. The Government of Indonesia established the Indonesian Foreign School (SILN) in Kuala Lumpur and Johor Bahru. In addition to SILN, there is also a 
Community Learning Center (CLC) which is organized for immigrant children who work in oil palm plantations (Kusmawardhani, 2018). CLC is spread throughout almost all oil palm plantations in Malaysia.

General education in Malaysia has several levels including; a) Preschool or Tadika, prep school before entering law school from 4-6 years old, b) Low schools (Darjah 1 to 6) which are usually entered by children aged 6-12 years. The National high school use Malay as their introduction. And a national high school that uses English, Mandarin or Tamil as the language of instruction. At the end of the 6th year, students will take a low school assessment exam (UPSR). c) Low School or 1-3 forms while level 4 and 5 are called high school or 4-5 forms where students are offered special programs such as science, literature and technology.Sixth Level Program (Form 6). At this level, students are given two choices whether in Science or literature. This level lasts about 1 year 6 months. After that, you will take the general exam ((Sijil Tinggi Persekolahan Malaysia)) STPM. The results of examination determine the acceptance of students at the University level, d) Pre-University Education, this education is a continuation of level 6, this education is prepared to enter the university level, Matriculation and External Education. SPM Exam (Sijil Pelajaran Malaysia), e) Matriculation Program, graduates from this Foundation will get a graduation certificate that is only valid at the University of Malaysia, f) Professional Bachelor Program (Undergraduate Degree), This program is better known as $2+1$ where 2 years of study in the country and continued the following year at the overseas Institute to get a bachelor's degree.

Generally, the migrants who have legal documents and earn more than RM5.000 are able to provide proper education to their children. This is because the government of Malaysia gives the requirements to the migrants who want to bring their families, they must earn more than RM5000. The problem is illegal migrants who marry in Malaysia then the children from this family will have difficulty accessing education. Especially, you live in rural areas such as in oil palm plantations.

\section{Food or consumption needs}

The migrant population is not too troubled with the fulfilment of basic needs because the salary they earn is still relatively large. The price of basic needs is relatively cheap. The price of a simple plate of rice is RM3. If eating with a rather luxurious portion costs is around RM10. The cost of eating alone ranges is from RM700 to RM1000. This fee can increase or decrease depending on the menu choice. Costs incurred will be cheaper if cooking food alone. It only costs around RM400 a month.

\section{Housing}

Having your own home on your own land is the desire of every family. But if the area is an advanced city it will certainly be difficult to make it happen. It is difficult for local residents, especially for those who are migrants. Apart from the expensive price, also taking care of the licensing is very difficult. This is a common problem because a city usually already has a spatial plan. The Malaysian government holds a "Malaysia My Second Home" program abbreviated as MM2H. This program is held for immigrants who want to stay for a long time in Malaysia. For migrants who interested in this program, they can submit an application to the government. Later the applicant will be divided into 2 groups. The first group is applicants aged 50 years and over with the following conditions; 1) has a minimum savings of RM 350,000, 2) have income from outside Malaysia at least RM10,000 per month. The second group is applicants under 50 years old with the following requirements: 1) have a minimum savings of RM500,000. 2) having income from outside Malaysia, minimum RM10,000 per month. By looking at the above requirements, it would not be easy for a migrant to own a house or land in Malaysia. Only rich people are able to fulfil it. For foreign workers, the employer is responsible for providing housing facilities to facilitate the process of monitoring and preventing the occurrence of social problems

Usually, migrants who live almost evenly in Kuala Lumpur, where they concentrate as in Chow Kit, Gombak, SelanggorKampungbakarbatu Perling, Johor and Mentari Court (Petaling Jaya). Rent houses prices in Kuala Lumpur are quite expensive. For a simple house that has two bedrooms and 1 bathroom ranging from RM500 to RM1000 per month. Actually, this also depends on the facilities and conditions of the house. The closer to public facilities, the more expensive the rent will be. The non-family migrants will rent a house together wth his friends so that the cost is cheaper. Some newcomers already have their own houses, this 
purchase they have done since decades ago. Before the existence of legislation governing about this land, some immigrants who come to Malaysia then stay temporarily in a family home.

\section{Health}

The source of Public health fund in Malaysia comes from taxes issued directly to the central government, annual income budget, SOSCO and EPF. This fund is also used for health programs and promotions, health facilities, inspection, hygiene control, quality control of food and water and health services (Lubnah, 2014). There are 4 types of social programs in Malaysia. 1) Employee Provident Fund (EPF) is a collection of workers' savings money that Mandatory savings for private workers in the KSWP Law. 2) The Social Security Organization (SOSCO) is an accident and pension insurance program for private workers. 3) Pension System for Civil Servants (PSCS) is a state employee pension program financed by the State Budget. 4) Armed Forces Savings Board (AFSB) is a retired military personnel program funded by the National Budget. (Purwoko, 2014).

The Official Portal of the Ministry of Health of Malaysia informs the Government that medical treatment for minor illness is only RM1 applies in public hospitals, sub-district and polyclinic hospitals. At specialist hospitals, it is around RM5 for every treatment. It is RM30 for the cost of the first visit of a private hospital and then charged RM5. Whereas for services outside the hospital is RM150 for each visit. For immigrants who have health insurance, they will get a cheap health service which is RM15. While illegal immigrants can only access health by meeting directly outside official services, this will result in expensive medical expenses, namely RM150 for once treatment. This will certainly have a negative impact on them if they got the disease

\section{Conclusion}

For the income of the migrants, their income is sufficient to meet their needs. They feel their income is bigger than in their home country. One of the reasons is because the Malaysian Ringgit exchange rate is higher than the currency in their country. So that some migrants can send money to their home countries. The Malaysian government pays attention to the education of immigrant children by allowing them to attend public schools except for foreigners without permission (PATI). Malaysia also gives permission to foreign countries to establish expatriate schools for residents who live in Malaysia so that they can obtain an education in accordance with the curriculum and language of the country. In general, the place of residence of newcomers has been provided by the employer, rented or stayed in his own house. If the employer does not provide the residence, the immigrants will look for lodging places that are far from the centre of the city. It is because they want a cheaper rental price. In terms of food or consumption needs, immigrants claim to have no problems, because the cost of consumption is cheap enough to be purchased directly or cooked by themselves. Health services for newcomers are relatively cheap, which is about RM15 for foreigners except for those who are foreigners without permission (PATI), because it will be counted as a service outside the hospital, which is RM150.

\section{References}

Hermon, D., Khairani., Daswirman., S. Karim., Dasrizal., and Triyatno. 2008. Metode dan Teknik Penelitian Geografi Tanah: Aplikasi Instrumen dan Acuan Penelitian Geografi Fisik. Yayasan Jihadul Khair Center.

Hermon, D. 2010. Geografi Lingkungan: Perubahan Lingkungan Global. UNP Press.

Hermon, D. 2012. Mitigasi Bencana Hidrometeorlogi: Banjir, Longsor, Degradasi Lahan, Ekologi, Kekeringan, dan Puting Beliung. UNP Press. Padang.

Hermon, D. 2015. Geografi Bencana Alam. Jakarta: PT RajaGrafindo Persada.

Hermon, D. 2016a. Mitigasi Perubahan Iklim. Rajawali Pers (Radjagrafindo). 
Hermon, D. 2016b. The Strategic Model of Tsunami Based in Coastal Ecotourism Development at Mandeh Regions, West Sumatera, Indonesia.Journal of Environment and Earth Science. Volume 6.

Hermon, D. 2017. Climate Change Mitigation. Rajawali Pers (Radjagrafindo).

Hermon, D., Suasti, Yurni., Ernawati., Afdhal., and Edial, Helfia. 2018. Geografi: Geografi untuk SMU. Jurusan Geografi Universitas Negeri Padang.

Fauzi, M. S and M.. Ridhwan. 2014. Warped Between the Ideal and Reality: Laws and the Foreign labour in Malaysia. GEOGRAFIA OnlineTM Malaysian Journal of Society and space 10 issue (101-109) 2014, ISSN 2180-2491

Kusmawardhani, A. 2018. Pendidikan anak TKI di Malaysia Menjadi Perhatian http://kabar24.bisnis.com/read/20180629/15/811017/pendidikan-anak-tki-di-malaysia-jadi-perhatian diakses 13 Agustus 2018

Lubnah. 2014. Sistem Pelayanan Kesehatan di Malaysia. http://www.Lubnah1992.blogspot.com/ 2014/05/sistem-pelayanan-kesehatan-di-Malaysia

Mohd, H. A. 2018. Pendatang Asing Tanpa Izin 'Bermasyarakat' di Malaysia. http://www.kosmo.com.my /jurnal/pendatang-asing-tanpa-izin-bermasyarakat-di-malaysia-1.638431 diakses 12 Agustus 2018

Norliati, N. F., M.D Nor and U. H. Yaakob. 2014. Perubahan Komposisi Penduduk Malaysia 1970-2010. International Journal of Environment, Society and Space 2014, 2 (2) , 10-20

Nuzuliani, A., R. N. Nurwati and B. M. Taftazani. 2013. Eksistensi Pekerja Sosial di Indonesia, Malaysia dan Amerika Serikat.

Portal Rasmi Kementrian Kesihatan Malaysia. http://www.moh.gov.my diakses 24 Agustus 2018 